\title{
Prevalence of hypospadias patients with undescended testis
}

\author{
Abrar Arbhiwa Tanguirsyaf Siregar ${ }^{1}$, Shalita Dastamuar ${ }^{2}$, Theodorus ${ }^{3}$, Marta Hendry ${ }^{4}$ \\ ${ }^{1}$ Medical School, Faculty of Medicine, Sriwijaya University, Indonesia \\ ${ }^{2,4}$ Department of Surgery, Faculty of Medicine, Sriwijaya University, Indonesia \\ ${ }^{3}$ Medical Research Unit, Faculty of Medicine, Sriwijaya University, Indonesia
}

\begin{tabular}{|c|c|}
\hline Article Info & ABSTRACT \\
\hline Article history: & Hypospadias is an anomaly of meatus urethra externus on ventral penis. \\
\hline Received Mar 10, 2019 & It caused by incomplete fusion of urethral folds. The purpose of this study \\
\hline Revised Apr 13, 2019 & the Department of Surgery Mohammad Hoesin Hospital in Palembang \\
\hline Accepted May 28, 2019 & $\begin{array}{l}\text { Indonesia. A prevalence study was done in the Medical Records Department } \\
\text { of Mohammad Hoesin Hospital from July } 2018 \text { to February of } 2019 .\end{array}$ \\
\hline Keywords: & $\begin{array}{l}103 \text { patients met study inclusion criteria. Univariate analysis of the patients' } \\
\text { data was conducted using IBM SPSS Statistics } 25 \text {. The study found that }\end{array}$ \\
\hline Hypospadias & hypospadias was most common in the age group of 1 to 5 years old $(49.5 \%)$ \\
\hline Patient & $\begin{array}{l}\text { and the most common type of hypospadias was severe hypospadias }(68.9 \%) \text {. } \\
\text { Furthermore } 7 \text { out of } 103 \text { patients }(6.8 \%) \text { were hypospadias patients with }\end{array}$ \\
\hline Prevalence study & undescended testis and the most common types of undescended testis among \\
\hline Undescended testis & $\begin{array}{l}\text { them were bilateral undescended testis and left undescended testis with } 3 \\
\text { patients each }(42.85 \%) \text {. Prevalence of hypospadias with undescended testis } \\
\text { were } 7 \text { patients }(6.8 \%) \text {. }\end{array}$ \\
\hline
\end{tabular}

Copyright @ 2019 Institute of Advanced Engineering and Science. All rights reserved.

\section{Corresponding Author:}

Abrar Arbhiwa Tanguirsyaf Siregar,

Bachelor Students of Medical School,

Faculty of Medicine, Sriwijaya University,

Palembang, Indonesia.

Email: abrararbhiwa@gmail.com

\section{INTRODUCTION}

Hypospadias is a genital development anomaly characterized by meatus urethra externus opening on the ventral surface of penis. It is caused by incomplete fusion of urethral folds [1]. Hypospadias is one of the most common congenital anomaly with the occurrence of 0.4 to 8.2 per 1,000 male births [2-3]. Prevalence of hypospadias around the world varies in numbers, from the lowest of 0.6 per 10,000 births in Malaysia and the highest of 464 per 10,000 births in Denmark [4]. Based on Birth Defects Monitoring Program (BDMP), Paulozzi reported that prevalence of hypospadias from 1970 to 1993 increased from 20.2 to 39.2 per 10,000 births. From 2001 to 2010, the prevalence of hypospadias in 23 European countries was 18.61 per 10,000 births [5]. Meanwhile in Indonesia, prevalence of hypospadias is still largely unclear. In Sanglah Hospital in Denpasar Bali, from 53 hypospadias patients treated from January 2009 to April 2012, only 27 patients have complete medical record. And in West Java, the number of hypospadias cases from 2010 to 2012 are reported to be 120 cases [6-7].

Hypospadias is also associated to other anomalies. The most common anomalies related to hypospadias are inguinal hernia and undescended testis (UDT). These anomalies appeared on $7-13 \%$ of hypospadias patients with greater occurrence on proximal hypospadias cases [1]. Approximately $10 \%$ of boys with hypospadias have undescended testis [8]. Hypospadias and UDT are often diagnosed as Disorders of Sex Development (DSD) as criteria that suggest DSD include overt genital ambiguity, apparent female genitalia with an enlarged clitoris, posterior labial fusion or an inguinal/labial mass, apparent male genitalia with bilateral undescended testes, hypospadias or micropenis, and discordance between prenatal karyotype 
and genital appearance [9]. When hypospadias is found with other criteria of DSD including undescended testis, it requires an evaluation with karyotype screening [1]. There has been no prevalence study on hypospadias with undescended testis in Indonesia. This prevalence study aimed to determine the prevalence of hypospadias with undescended testis in the Department of Surgery Mohammad Hoesin Hospital Palembang in Indonesia.

\section{RESEARCH METHOD}

This prevalence study has been done in Medical Records Department of Mohammad Hoesin Hospital Palembang from July 2018 to February 2019. The sample of this study was those fulfilling the inclusion criteria which were all patients suspected of hypospadias in the Department of Surgery Mohammad Hoesin Hospital Palembang during the period of 2016-2017, and patients with completed medical reports. The data used in this study was secondary data obtained from Medical Records Department of Mohammad Hoesin Hospital. The data was derived from the medical records of patients who was treated by the Department of SurgeryMohammad Hoesin Hospital Palembang during 2016-2017 period. The data were analyzed using univariate analysis to produce descriptive table with several predetermined variables including the age group of the hypospadias patient, the hypospadias type, history of undescended testis in the hypospadias patients, and types of the undescended testis on hypospadias patients with undescended testis. The protocol has been approved by ethical committee of Faculty of Medicine Sriwijaya University.

\section{RESULTS AND DISCUSSIONS}

From the 183 hypospadias patients in Mohammad Hoesin Hospital during 2016-2017 period, 103 met the inclusion criteria.

\subsection{Age groups of hypospadias patient}

The patients were divided into several age groups, namely: 0-5 months, 6-11 months, 1-5 years old, 6-10 years old, 11-14 years old, and 15-19 years old. During 2016-2017, hypospadias patient on the age group of 1-5 years old was the most common in the Department of Surgery Mohammad Hoesin Hospital with 51 patients (49.5\%). It was followed by 6-10 years old with 34 patients (33\%), 0-5 months with 8 patients (8\%), 11-14 years old with 7 patients (7\%), and 6-11 months with 2 patients $(1.9 \%)$. The least common age group of the hypospadias patient was 15-19 years old with 1 patient (1\%). Table 1 shows the groups of age among patients.

Table 1. Hypospadias based on age groups in Department of Surgery Mohammad Hoesin Hospital

\begin{tabular}{ccc}
\multicolumn{3}{c}{$2016-2017$} \\
\hline Age group & $\mathrm{n}$ & $\%$ \\
\hline $0-5$ months & 8 & 7.8 \\
$6-11$ months & 2 & 1.9 \\
$1-5$ years & 51 & 49.5 \\
$6-10$ years & 34 & 33.0 \\
$11-14$ years & 7 & 6.8 \\
$15-19$ years & 1 & 1.0 \\
\hline Total & 103 & 100 \\
\hline
\end{tabular}

The most common age group of hypospadias patients in Mohammad Hoesin Hospital during 2016-2017 period was 1-5 years old with 51 patients $(49.5 \%)$. The optimal age of genital operation is between 6 to 12 months [10]. If the operation could not be done earlier or the anomaly was found when patient was 1 year old or above, the opportunity to have the operation at the age of 3-4 years old is still possible [11]. However, in developing countries due to late awareness, ignorance of the anomaly, and unaffordability to have the operation, the average age of hypospadias patients brought to hospital is 5 years old [12]. These may also be the reasons to why the most common age group of hypospadias patient is $1-5$ years old.

\subsection{Classification of hypospadias}

Based on the classification of hypospadias, the most common type of hypospadias was severe hypospadias with 71 patients $(68.9 \%)$. Meanwhile, 18 patients $(17.5 \%)$ have moderate or middle hypospadias, and 14 patients $(13.6 \%)$ have mild hypospadias. Table 2 reveals the severity among patients. 
Table 2. Divided severity of hypospadias

\begin{tabular}{ccc}
\hline Type of hypospadias & $\mathrm{n}$ & $\%$ \\
\hline Mild Hypospadias & 14 & 13.6 \\
Middle Hypospadias & 18 & 17.5 \\
Severe Hypospadias & 71 & 68.9 \\
\hline Total & 103 & $100 \%$ \\
\hline
\end{tabular}

Majority of severe hypospadia in the Department of Surgery Mohammad Hoesin Hospital were penoscrotal hypospadias which meatus urehtra externus located between proximal shaft of penis and scrotum. This result corresponds to Itesako et al. research which reported severe hypospadias as more common than moderate hypospadias and mild hypospadias [13]. However, this result differs to what is reported in other literature where the most common type of hypospadias was mild hypospadias with $50 \%$ or $65-70 \%$ of all hypospadias cases in world $[1,14]$. The number of mild or distal hypospadias patients was the smallest in Mohammad Hoesin Hospital Palembang might be caused by the unawareness of patients with mild hypospadias on their condition resulting to them not coming to the hospital for examination and treatment or because Dr. Mohammad Hoesin Hospital Palembang is the top hospital in the region so severe hypospadias cases were referred or directed to the hospital more.

\subsection{History of undescended testis in hypospadias patients}

The majority of hypospadias patients did not have undescended testis with 96 patients (93.2\%), while the other 7 patients $(6.8 \%)$ have a history of undescended testis. Table 3 describes the history of undescended testis among patients.

Table 3. History of undescended testis in hypospadias patients

\begin{tabular}{ccc}
\hline History of Undescended testis & $\mathrm{n}$ & $\%$ \\
\hline Have & 7 & 6.8 \\
No & 96 & 93.2 \\
\hline Total & 103 & 100 \\
\hline
\end{tabular}

Compared to other studies of hypospadias with undescended testis, this study has similar result. In the study by Itesako et al., from 466 hypospadias patients, 29 patients $(6.2 \%)$ have congenital undescended testis and 15 patients (3.2\%) have acquired undescended testis [13]. And from Wu et al. research, 26 of 352 hypospadias patients $(7.3 \%)$ have undescended testis [15].

\subsection{Type of undescended testis and hypospadias in hypospadias patients with undescended testis}

Of the seven hypospadias patients with undescended testis, not only three hypospadias patients $(42.85 \%)$ with bilateral undescended testes, but also three patients $(42.85 \%)$ with left undescended testis. On the other hand, only one patient (14.3\%) with history of right undescended testis is shown in Table 4.

Table 4. Classification of undescended testis in hypospadias patients with history of undescended testis

\begin{tabular}{ccc}
\hline Types of Undescended Testis & $\mathrm{n}$ & $\%$ \\
\hline Bilateral & 3 & 42.85 \\
Left & 3 & 42.85 \\
Right & 1 & 14.3 \\
\hline Total & 7 & $100 \%$ \\
\hline
\end{tabular}

Table 5 shows that five patients $(71.4 \%)$ with severe hypospadias. It was the most common types of hypospadias among hypospadias patients with history of undescended testis. Meanwhile, not only one patient $(14.3 \%)$ has mild hypospadias, but also moderate hypospadias only have one patient $(14.3 \%)$.

Table 5. Type of hypospadias with history of undescended testis

\begin{tabular}{ccc}
\hline Type of Hypospadias & $\mathrm{N}$ & $\%$ \\
\hline Mild Hypospadias & 1 & 14.3 \\
Moderate Hypospadias & 1 & 14.3 \\
Severe Hypospadias & 5 & 71.4 \\
\hline Total & 7 & $100 \%$ \\
\hline
\end{tabular}

Int. J. Public Health Sci. Vol. 8, No. 2, June 2019: 158 - 162 
This result is in line with Wu et al. study that reported that from three types of hypospadias-anterior hypospadias, mid-penile hypospadias, and posterior/proximal hypospadias-undescended testis was most common on patients with posterior hypospadias than the others [15]. Similar result was reported by Itesako et al. Study where congenital undescended testis and acquired undescended testis appeared most on proximal or severe hypospadias [13]. According to Taisen et al. study, risk of undescended testis in hypospadias patients is higher on patients with proximal hypospadias, however the risk factors associating hypospadias and undescended testis is still unclear so the reasons to why undescended testis most often appeared on proximal hypospadias than the other types is still unknown $[13,16]$.

\subsection{Age group in hypospadias patients with undescended testis}

Table 6 reveals that the most common age group of hypospadias patients with undescended testis was $1-5$ years old with 5 patients $(71.4 \%)$.

Table 6. Age groups of hypospadias patients with history of undescended testis

\begin{tabular}{ccc}
\hline Age groups & $\mathrm{n}$ & $\%$ \\
\hline $0-6$ months & 1 & 14.3 \\
$1-5$ years & 5 & 71.4 \\
$6-10$ years & 1 & 14.3 \\
\hline Total & 7 & $100 \%$ \\
\hline
\end{tabular}

Diagnosis and early treatment of undescended testis at the age of 6-12 months is important to prevent loss of germ cell and increase patient's fertility index especially as it is during those age that one's gonocyte changes into dark type Ad spermatogonia [17]. If operation on patients with undescended testis was carried out late, the patient's risk of testicular cancer and infertility would increase. According to Pettersson et al., the relative risk of testicular cancer on undescended testis patients who have done orchidopexy before 13 years old was 2.23 and after 13 years old was 5.40 [18]. As reported by Shiryazdi et al., the main reason to delayed treatment and early diagnosis of undescended testis was the failure of the physician in diagnosing undescended testis at birth or during follow-up period and the lack of awareness of the parents on the location of the testis, although this lateness can be prevented if diagnosis and treatment are done before the age of 18 months old [19].

\section{CONCLUSION}

Prevalence of hypospadias with undescended testis in the Department of Surgery Mohammad Hoesin Hospital during 2016-2017 period was 7 (6.8\%) out of 103 hypospadias patients and the most common types of undescended testis was bilateral and left undescended testis with 3 patients each $(42.85 \%)$. The most common age group on hypospadias patient with undescended testis was 1-5 years with 5 patients $(71.4 \%)$. The most common type of hypospadias in hypospadias patients with undescended testis is severe hypospadias with 5 patients $(71.4 \%)$.

\section{REFERENCES}

[1] Murphy JP. Hypospadias. In: Holcomb GW, Murphy JP, Ostlie DJ, editors. Ashcraft's Pediatric Surgery E-Book. New York: Elsevier Health Sciences; 2014. p. 794-808.

[2] Gallentine ML, Morey AF, Thompson Jr IM. Hypospadias: a contemporary epidemiologic assessment. Urology. 2001 Apr 1;57(4):788-90.

[3] Albert N, Ulrichs C, Glüer S, Hiort O, Sinnecker GH, Mildenberger H, Brodehl J. Etiologic classification of severe hypospadias: implications for prognosis and management. The Journal of pediatrics. 1997 Sep 1;131(3):386-92.

[4] Springer A, Van Den Heijkant M, Baumann S. Worldwide prevalence of hypospadias. Journal of pediatric urology. 2016 Jun 1;12(3):152-e1.

[5] Bergman JE, Loane M, Vrijheid M, Pierini A, Nijman RJ, Addor MC, Barisic I, Béres J, Braz P, Budd J, Delaney V. Epidemiology of hypospadias in Europe: a registry-based study. World journal of urology. 2015 Dec 1;33(12):2159-67.

[6] Duarsa GW, Nugroho TD. Characteristics of hypospadias cases in Sanglah general hospital, Bali-Indonesia: a descriptive study. Bali Med J. 2016 Jan 1;5(1):13-6.

[7] Maritska Z, Santosa A, Ariani MD, Juniarto AZ, Faradz SM. Profile of hypospadias cases in Central Java, Indonesia. Journal of Biomedicine and Translational Research. 2015 Aug 28;1(1):16-21.

[8] Elder JS. Anomalies of the Penis and Urethra. In: Kliegman RM, Behrman RE, Jenson HB, Stanton BM, editors. Nelson Textbook of Pediatrics E-Book. Philadelphia: Elsevier Health Sciences; 2007. p. 2586 - 2691 
[9] Lee PA, Houk CP, Ahmed SF, Hughes IA. Consensus statement on management of intersex disorders. Pediatrics. 2006 Aug 1;118(2):e488-500.

[10] American Academy of Pediatrics. Timing of elective surgery on the genitalia of male children with particular reference to the risks, benefits and psychological effects of surgery and anesthesia. Pediatrics. 1996;97:590-4.

[11] Manzoni G, Bracka A, Palminteri E, Marrocco G. Hypospadias surgery: when, what and by whom?. BJU international. 2004 Nov;94(8):1188-95.

[12] Bhat A. Extended urethral mobilization in incised plate urethroplasty for severe hypospadias: a variation in technique to improve chordee correction. The Journal of urology. 2007 Sep 1;178(3):1031-5.

[13] Itesako T, Nara K, Matsui F, Matsumoto F, Shimada K. Acquired undescended testes in boys with hypospadias. The Journal of urology. $2011 \mathrm{Jun} ; 185(6 \mathrm{~s}): 2440-3$.

[14] Baskin LS.Hypospadias. In: Coran AG, Caldamone A, Adzick NS, Krummel TM, Laberge JM, Shamberger R, editors. Pediatric Surgery E-Book Vol. 2. New York: Elsevier Health Sciences; 2012. p. 1531 - 1557.

[15] Wu WH, Chuang JH, Ting YC, Lee SY, Hsieh CS. Developmental anomalies and disabilities associated with hypospadias. The Journal of urology. $2002 \mathrm{Jul} ; 168(1): 229-32$.

[16] Tasian GE, Zaid H, Cabana MD, Baskin LS. Proximal hypospadias and risk of acquired cryptorchidism. The Journal of urology. 2010 Aug;184(2):715-20.

[17] Ekwunife OH, Ugwu JO, Onwurah C, Okoli CC, Epundu LK. Undescended Testes: Contemporary Factors Accounting for Late Presentation. African Journal of Urology. 2018;24(3):206-11.

[18] Pettersson A, Richiardi L, Nordenskjold A, Kaijser M, Akre O. Age at surgery for undescended testis and risk of testicular cancer. New England Journal of Medicine. 2007 May 3;356(18):1835-41.

[19] Shiryazdi SM, Modir A, Benrazavi S, Moosavi N, Kermani-Alghoraishi M, Ghahramani R. Causes of delay in proper treatment of patients with undescended testis. Iranian journal of reproductive medicine. 2011;9(1):37.

Int. J. Public Health Sci. Vol. 8, No. 2, June 2019: 158 - 162 